\title{
Long-term inhibition of dipeptidyl peptidase IV improves glucose tolerance and preserves islet function in mice
}

\author{
M Kvist Reimer, J J Holst ${ }^{1}$ and B Ahrén \\ Department of Medicine, Lund University, Lund, Sweden and ${ }^{1}$ Department of Medical Physiology, The Panum Institute, Copenhagen University, Denmark
}

(Correspondence should be addressed to B Ahrén; Email: Bo.Ahren@med.lu.se)

\begin{abstract}
Objectives: Inhibitors of the glucagon-like peptide-1 (GLP-1)-degrading enzyme, dipeptidyl peptidase IV (DPPIV), are being explored in the treatment of diabetes. We examined the long-term influence of a selective, orally active inhibitor of DPPIV (NVP DPP728), in normal female C57BL/6J mice and such mice rendered glucose-intolerant and insulin-resistant by feeding a high-fat diet.

Design: In mice fed a standard diet (11\% fat) or a high-fat diet (58\% fat), NVP DPP728 $(0.12 \mu \mathrm{mol} / \mathrm{g}$ body weight) was administered in the drinking water for an 8 week period.

Results: DPPIV inhibition reduced plasma DPPIV activity to $0.01 \pm 0.03 \mathrm{mU} / \mathrm{ml}$ vs $3.26 \pm 0.19 \mathrm{mU} / \mathrm{ml}$ in controls $(P<0.001)$. Glucose tolerance after gastric glucose gavage, as judged by the area under the curve for plasma glucose levels over the $120 \mathrm{~min}$ study period, was increased after 8 weeks by NVP DPP728 in mice fed normal diet $(P=0.029)$ and in mice fed a high-fat diet $(P=0.036)$. This was accompanied by increased plasma levels of insulin and intact GLP-1. Glucose-stimulated insulin secretion from islets isolated from NVP DPP728-treated animals after 8 weeks of treatment was increased as compared with islets from control animals at $5.6,8.3$ and $11.1 \mathrm{mmol} / \mathrm{l}$ glucose both in mice fed normal diet and in mice fed a high-fat diet (both $P<0.05$ ). Islet insulin and glucagon immunocytochemistry revealed that NVP DPP728 did not affect the islet architecture. However, the expression of immunoreactive glucose transporter isoform-2 (GLUT-2) was increased by DPPIV inhibition, and in mice fed a high-fat diet, islet size was reduced after treatment with NVP DPP728 from $16.7 \pm 2.6 \times 10^{3} \mu \mathrm{m}^{2}$ in controls to $7.6 \pm 1.0 \times 10^{3} \mu \mathrm{m}^{2}(P=0.0019)$.

Conclusion: Long-term DPPIV inhibition improves glucose tolerance in both normal and glucose-intolerant mice through improved islet function as judged by increased GLUT-2 expression, increased insulin secretion and protection from increased islet size in insulin resistance.
\end{abstract}

European Journal of Endocrinology 146 717-727

\section{Introduction}

The gut incretin hormones, glucagon-like peptide-1 (GLP-1) and gastric inhibitory polypeptide (GIP) are both released in response to ingested nutrients and they both augment insulin secretion (1-3). They are of main importance for a normal glucose tolerance after meal intake, as is illustrated by studies showing that GLP-1 and GIP receptor antagonists induce glucose intolerance in humans and rats $(4,5)$, and that mice having a genetic deletion of their respective receptors display glucose intolerance after oral glucose $(6,7)$. GLP-1 is also considered a potential therapeutic agent for type 2 diabetes because it stimulates insulin secretion in a glucose-dependent manner, inhibits glucagon secretion and delays gastric emptying, which together result in reduced circulating glucose (3). However, the usefulness of GLP-1 in the treatment of diabetes is hampered by the short half-life of the hormone, being only approximately $1 \mathrm{~min}(8)$, because the clearance of the peptide is larger than cardiac output. This makes GLP-1 unattractive for chronic therapy because multiple daily injections or continuous infusion by devices would be required to achieve sustained glycemic control. One approach to overcome this drawback is to inhibit the degradation of endogenously secreted GLP-1 to prolong the circulating half-life of the hormone (8). The enzyme responsible for the degradation of GLP-1, and also for GIP, is dipeptidyl peptidase IV (DPPIV), which is an enzyme distributed throughout the body both in plasma and in the endothelial lining of several organs, such as kidney, liver and intestine (9). It cleaves a number of biologically active peptides by removing the first two N-terminal amino acids provided that the amino acid in position two is proline or alanine, as in GLP-1 and GIP (911). The resulting N-terminally truncated forms of GLP-1 and GIP are devoid of insulinotropic activity $(8,12)$ and, therefore, the degradation of the peptides by DPPIV is an inactivation process. In fact, the 
degradation of GLP-1 and GIP by DPPIV is the major inactivation mechanism of these incretins and the cause of their short half-lives $(8,13,14)$. Consequently, inhibition of DPPIV considerably increases the levels and prolongs the circulating half-lives of the active form of the two hormones $(8,15-17)$. Therefore, DPPIV inhibition will be antidiabetogenic, which is illustrated by findings that DPPIV-deficient mice and rats show improved glucose tolerance and increased insulin secretion after oral glucose $(18,19)$. Hence, DPPIV is a new potential target for treatment of diabetes (8). A few studies have also examined this possibility by using pharmacological inhibition of DPPIV in short-term experiments.

Thus, in short-term studies, pharmacological inhibition of DPPIV has been shown to improve glucose tolerance in Zucker rats using both isoleucine thiazolidide (20) and the selective, orally active inhibitor NVP DPP728 (16), and in mice fed high-fat diet (17) and in Fischer rats (19) using valine pyrrolidide. A recent preliminary study has also demonstrated that NVP DPP728 improves glucose tolerance in human subjects with type 2 diabetes (21). However, since these previous studies examined the influence of DPPIV inhibition only on a short-term basis, the long-term effects of DPPIV inhibition have not been studied. On a long-term basis, additional effects of the incretins may be achieved, because GLP-1 stimulates insulin gene transcription and biosynthesis $(22,23)$ and augments beta-cell differentiation and growth (24). To examine the long-term effects of DPPIV inhibition, we have in this study examined the influence on glucose tolerance, insulin secretion and islet morphology of 8 weeks of inhibition of DPPIV in C57BL/6J mice rendered glucose-intolerant by feeding a high-fat diet. We have previously shown that high-fat feeding of $\mathrm{C} 57 \mathrm{BL} / 6 \mathrm{~J}$ mice results in glucose intolerance (25), which is improved by acute administration of the DPPIV inhibitor valine pyrrolidide, in conjunction with increased insulin secretion (17). We have also previously shown that exogenous administration of GLP-1 to mice of this strain fed a high-fat diet results in an augmented insulin response when compared with the response in mice fed normal diet, as a sign of upregulated GLP-1 signaling (26). This is in partial contradiction to a study in humans with impaired glucose tolerance where the insulin response to GLP-1 has been shown to be impaired (27), although preserved GLP-1 action has also been demonstrated in subjects with type 2 diabetes (28). However, the preserved or augmented insulin response to GLP-1 in the mouse model fed a high fat diet suggests that this mouse model would be of particular interest for evaluating the potential influence of DPPIV inhibition on islet function and glucose tolerance. In the present study, longterm DPPIV inhibition was achieved by means of NVP DPP728 administered in the drinking water. NVP DPP728 is an orally active, highly selective and highly potent inhibitor of DPPIV (29).

\section{Materials and methods}

\section{Animals}

Female mice of the C57BL/6J strain were obtained from M\&B A/S, Ry, Denmark, at 4 weeks of age. One week after arrival, the mice were given either a high-fat diet or an ordinary rodent chow diet (both diets from Research Diets, New Brunswick, NJ, USA). On a caloric base, the high-fat diet consisted of $16.4 \%$ protein, $25.6 \%$ carbohydrates and $58.0 \%$ fat (total $23.4 \mathrm{~kJ} / \mathrm{g}$ ), whereas the control diet consisted of $25.8 \%$ protein, $62.8 \%$ carbohydrates and $11.4 \%$ fat (total $12.6 \mathrm{~kJ} / \mathrm{g}$ ). Throughout the study period, the mice had free access to food and water. Five mice were kept per cage in a temperature-controlled $\left(22^{\circ} \mathrm{C}\right)$ room with a $12 \mathrm{~h}$ light: $12 \mathrm{~h}$ darkness cycle with lights on at $0600 \mathrm{~h}$. The study was approved by the Animal Ethics Committee at Lund University.

\section{Experiments}

At 5 weeks of age, the mice were divided into four groups given normal or high-fat diet, each of these groups being subdivided into one control group and one group given NVP DPP728. NVP DPP728 (kind gift from Novartis Pharmaceutical Corporation, East Hanover, NJ, USA) is water soluble and was added to the drinking water at a concentration of $1 \mu \mathrm{mol} / \mathrm{ml}$ water resulting in a daily dose of NVP DPP728 of $0.12 \mu \mathrm{mol} / \mathrm{g}$ body weight. The study lasted for 8 weeks. Body weight, food and water intake were regularly measured. After 1 week, blood samples were taken at 1000 and $1600 \mathrm{~h}$, and at $1000 \mathrm{~h}$ the next day in NVP DPP728-treated mice, and at $1000 \mathrm{~h}$ in control mice for measurement of plasma DPPIV activity. After 4 and 8 weeks, an oral glucose tolerance test was carried out, and at the end of the 8 week study period pancreatic islets were isolated for the in vitro study of glucose-stimulated insulin secretion or the whole pancreas was taken for morphological analysis.

\section{Gastric glucose gavage}

Mice fasted for $2 \mathrm{~h}$ were anesthetized with an i.p. injection of $0.14 \mathrm{mg} / \mathrm{mouse}$ midazolam (Dormicum; Hoffman-La-Roche, Basel, Switzerland) and a combination of $0.9 \mathrm{mg} / \mathrm{mouse}$ fluanison and $0.02 \mathrm{mg} / \mathrm{mouse}$ fentanyl (Hypnorm; Janssen, Beerse, Belgium). At $30 \mathrm{~min}$ after induction of anesthesia, a baseline blood sample was taken from the retrobulbar, intraorbital, capillary plexus, whereafter $150 \mathrm{mg} / \mathrm{mouse}$ D-glucose (British Drug Houses Ltd, Poole, Dorset, UK) was administered through a gavage tube (volume load $0.25 \mathrm{ml}$ ). Thereafter, new blood samples were taken at 10, 30, 60, 90 and $120 \mathrm{~min}$. The samples were taken in heparinized pipettes and placed into tubes which were stored on ice. Following centrifugation, plasma was 
separated and stored at $-20{ }^{\circ} \mathrm{C}$ until analysis for glucose, insulin and intact GLP-1.

\section{Insulin secretion in vitro}

Pancreatic islets from the four groups of mice were isolated by collagenase digestion in Hanks' balanced salt solution (HBSS) (Sigma Chemical Co., Poole, Dorset, UK). In brief, after a midline laparatomy, the common bile duct was cannulated and ligated at the papilla Vateri. The pancreas was filled with $3 \mathrm{ml}$ ice-cold HBSS supplemented with $0.4 \mathrm{mg} / \mathrm{ml}$ collagenase $\mathrm{P}$ (Boehringer Mannheim GmbH, Mannheim, Germany) before removal and incubation at $37^{\circ} \mathrm{C}$ for $19 \mathrm{~min}$. After washing three times in modified HBSS, containing $125 \mathrm{mmol} / \mathrm{l} \mathrm{NaCl}, 5.9 \mathrm{mmol} / \mathrm{l} \mathrm{KCl}, 1.28 \mathrm{mmol} / \mathrm{l} \mathrm{CaCl}_{2}$, $1.2 \mathrm{mmol} / \mathrm{l} \mathrm{MgCl}_{2}, 25 \mathrm{mmol} / \mathrm{l}$ Hepes, $3.3 \mathrm{mmol} / \mathrm{l} \mathrm{glu}-$ cose and $0.1 \%$ human serum albumin ( $\mathrm{pH} 7.36)$, the islets were preincubated in the same medium for $60 \mathrm{~min}$. Thereafter, three islets were incubated in $100 \mu \mathrm{l}$ medium for $60 \mathrm{~min}$ at $37^{\circ} \mathrm{C}$ in the presence of different glucose concentrations. After incubation, aliquots of $25 \mu \mathrm{l}$ in duplicate were collected and stored at $-20{ }^{\circ} \mathrm{C}$ until analysis of insulin content.

\section{Analyses}

Plasma DPPIV activity was measured using an assay based on a modification described previously (15) of a published method (30). In brief, aliquots of plasma were incubated with substrate (Gly-Pro-AMC, where AMC is 7-amino-4-methylcoumarin) (Bachem, King of Prussia, PA, USA). Free AMC was generated in proportion to DPPIV activity and was measured by fluorimetry. Catalytic DPPIV activity is expressed as $\mathrm{mU} / \mathrm{ml}$, where $1 \mathrm{U}$ is equal to $1 \mu \mathrm{mol}$ substrate cleaved per minute. Plasma insulin was determined by RIA with the use of a guinea pig anti-rat insulin antibody, ${ }^{125} \mathrm{I}-$ labeled porcine insulin as tracer and rat insulin as standard (Linco Research, St Charles, MO, USA). Free and bound radioactivity were separated by use of an antiIgG (goat anti-guinea pig) antibody (Linco). N-terminal GLP-1 imunoreactivity was measured radioimmunochemically as described previously (31), except for the use of antiserum Her4 (D Bataille, Montpellier, France). This assay is specific for the intact N-terminus of GLP-1, and cross-reacts less than $0.1 \%$ with GLP1(9-36)amide, and approximately $2 \%$ with the structurally related peptides GLP-1(1-36)amide and the major proglucagon fragment (proglucagon(72-158)) secreted from the pancreas. Valine pyrrolidide (0.01 mmol/l final concentration) was added to the assay buffer to prevent N-terminal degradation of GLP-1 during the assay incubation. HPLC supports the use of RIAs with specificity for determination of intact GLP-1 (32). Plasma samples were extracted with $70 \%$ ethanol (v/v, final concentration) before assay, giving recoveries of $75 \%$ (33). Standard and
${ }^{125}$ I-labeled tracers were GLP-1(7-36)amide, and separation of bound from free peptide was achieved using plasma-coated charcoal. The intra-assay coefficient of variation was less than $6 \%$. Plasma glucose concentrations were determined with the glucose oxidase technique.

\section{Islet morphology}

Animals were killed under anesthesia by exsanguination and their pancreata were collected. The tissue specimens were fixed in Stefanini's fixative (4\% p-formaldehyde in $0.1 \mathrm{~mol} / \mathrm{l}$ PBS containing $0.1 \%$ picric acid) for at least $4 \mathrm{~h}$, washed in PBS and cryopreserved by immersion in 20\% (w/v) sucrose in PBS overnight. Pancreata were then frozen in OCT compound (Sakawa, Tokyo, Japan) and cryosectioned at $10 \mu \mathrm{m}$. Cryosections of pancreas were incubated with antibodies diluted in PBS containing $0.25 \%$ Triton-X and $0.25 \%$ BSA. Insulin was detected by a guinea pig anti-rat proinsulin antiserum (dilution 1:1280), glucagon by a rabbit anti-glicentin antiserum (dilution 1:10 560; both from Eurodiagnostica, Malmö, Sweden) and glucose transporter isoform-2 (GLUT-2) by a rabbit anti-rat GLUT-2 antiserum (34) (dilution 1:200) (from Chemicon International, Inc., Temecula, CA, USA). Antisera conjugated with Alexa fluorochromes were used as secondary antibodies (goat anti-guinea pig Alexa546 and goat anti-rabbit Alexa488 respectively, both diluted at 1:300) (Molecular Probes, Leiden, The Netherlands). In double-staining experiments, insulin and glucagon immunostaining was detected in an Olympus BX 51 microscope (Malmö, Sweden) allowing the visualization of Alexa488 and Alexa546 fluorochromes at the same time. Digital images of the specimen were made with an Olympus DP-50 camera and transferred to a personal computer equipped with the software NIH Image 1.06. Islet size was determined from the immunohistochemical staining by interactively defining the outline of each individual islet and the area covered was determined with NIH Image after calibration with a microscale. A total of five to seven sections from each pancreas was analyzed; pancreata were taken from eight animals in each group.

\section{Calculations and statistics}

Means \pm S.E.M. are shown. Areas under the curve (AUC) for plasma insulin levels $\left(\mathrm{AUC}_{\text {insulin }}\right)$ and plasma glucose levels $\left(\mathrm{AUC}_{\text {glucose }}\right)$ were calculated by the trapezoidal rule. Statistical analyses were performed with the Statistical Package for Social Sciences (SPSS) for Windows. Statistical comparisons between groups in vivo were performed with Student's $t$-test and the statistical comparison of the in vitro studies were performed by ANOVA. 


\section{Results}

\section{Body weight, food and water intake}

C57BL/6J mice were given high-fat diet from the age of 5 weeks for a period of 8 weeks. Fifty percent of the animals in each group (normal mice and mice fed high fat) were given the DPPIV inhibitor, NVP DPP728, in the drinking water. Figure 1 shows that body weight increased more in the high-fat diet group than in the normal diet group. Body weight was not affected by NVP DPP728. Nevertheless, food intake during the last week of the study was slightly lower in mice given NVP DPP728, both in those given normal diet $(1.7 \%$ lower, $P=0.046)$ and in those given high-fat diet $(9.1 \%$ lower, $P<0.001)$. Water intake averaged $2.7 \pm$ $0.2 \mathrm{ml} /$ mouse per day in mice fed normal diet vs $3.4 \pm$ $0.3 \mathrm{ml} /$ mouse per day in mice given high-fat diet, with no difference between control and NVP DPP728-treated mice. After correcting for the body weight, mice fed normal diet had a daily water intake of $0.13 \pm$ $0.01 \mathrm{ml} / \mathrm{g}$ body weight vs $0.12 \pm 0.01 \mathrm{ml} / \mathrm{g}$ body weight in mice fed high-fat diet $(P=0.529)$. This in turn resulted in an equivalent dose of NVP DPP728 for the two groups when expressed per gram body weight.

\section{Plasma DPPIV activity}

After 1 week of treatment with NVP DPP728, plasma DPPIV activity was determined. In samples taken at $1000 \mathrm{~h}$, plasma DPPIV activity was $3.26 \pm 0.19 \mathrm{mU} / \mathrm{ml}$ in control mice whereas in NVP DPP728-treated mice, plasma DPPIV activity was only $0.10 \pm 0.03 \mathrm{mU} / \mathrm{ml}$ $(P<0.001)$. There was no difference between normal diet mice and mice fed high-fat diet. In NVP DPP728-treated mice, plasma DPPIV activity was very low also in samples taken at $1600 \mathrm{~h}(0.29 \pm$ $0.17 \mathrm{mU} / \mathrm{ml})$ and at $1000 \mathrm{~h}$ the next day $(0.10 \pm$ $0.11 \mathrm{mU} / \mathrm{ml})$. Hence, NVP DPP728 markedly reduced the $24 \mathrm{~h}$ plasma DPPIV activity.

\section{Glucose and insulin after gastric glucose}

After 4 and 8 weeks, glucose was given by gastric gavage in all four groups of mice. Figures 2 and 3 show the glucose and insulin data and Table 1 the $\mathrm{AUC}_{\text {glucose }}$ and $\mathrm{AUC}_{\text {insulin }}$ during the $120 \mathrm{~min}$ study period. In mice fed a normal diet, glucose levels were reduced after the glucose load by NVP DPP728 after both 4 and 8 weeks and this was accompanied by increased insulin response. In mice fed high-fat diet, glucose levels after the glucose load were significantly reduced by NVP DPP728 after 8 weeks but not significantly after 4 weeks, although the insulin responses were increased after both 4 and 8 weeks. Glucose levels were in general higher after 4 than after 8 weeks in mice fed both normal diet and high-fat diet, which most likely is due to different distribution kinetics of glucose in growing mice. For that reason, it is possible only to compare mice of the same age.

\section{GLP-1 after gastric glucose}

Plasma levels of intact GLP-1 increased after the glucose gavage in mice with the peak level seen at 10 min (Figs 2 and 3). The increase in GLP-1 levels after gastric glucose showed a tendency to be exaggerated in NVP DPP728-treated animals at both 4 and 8 weeks, although these differences did not reach statistical significance. However, when combining the two tests together, a significantly exaggerated $10 \mathrm{~min}$ GLP1 response was evident in NVP DPP728-treated animals, both in the group given normal diet (10 min $\Delta$ being $17 \pm 3$ vs $4 \pm 2 \mathrm{pmol} / \mathrm{l}, P=0.021$ ) and in the group given high-fat diet ( $10 \mathrm{~min} \Delta$ being $12 \pm 2$ vs $5 \pm 2 \mathrm{pmol} / \mathrm{l}, P=0.034)$.

\section{Insulin secretion in vitro}

After 8 weeks of study, islets were isolated and glucosestimulated insulin secretion was examined following a

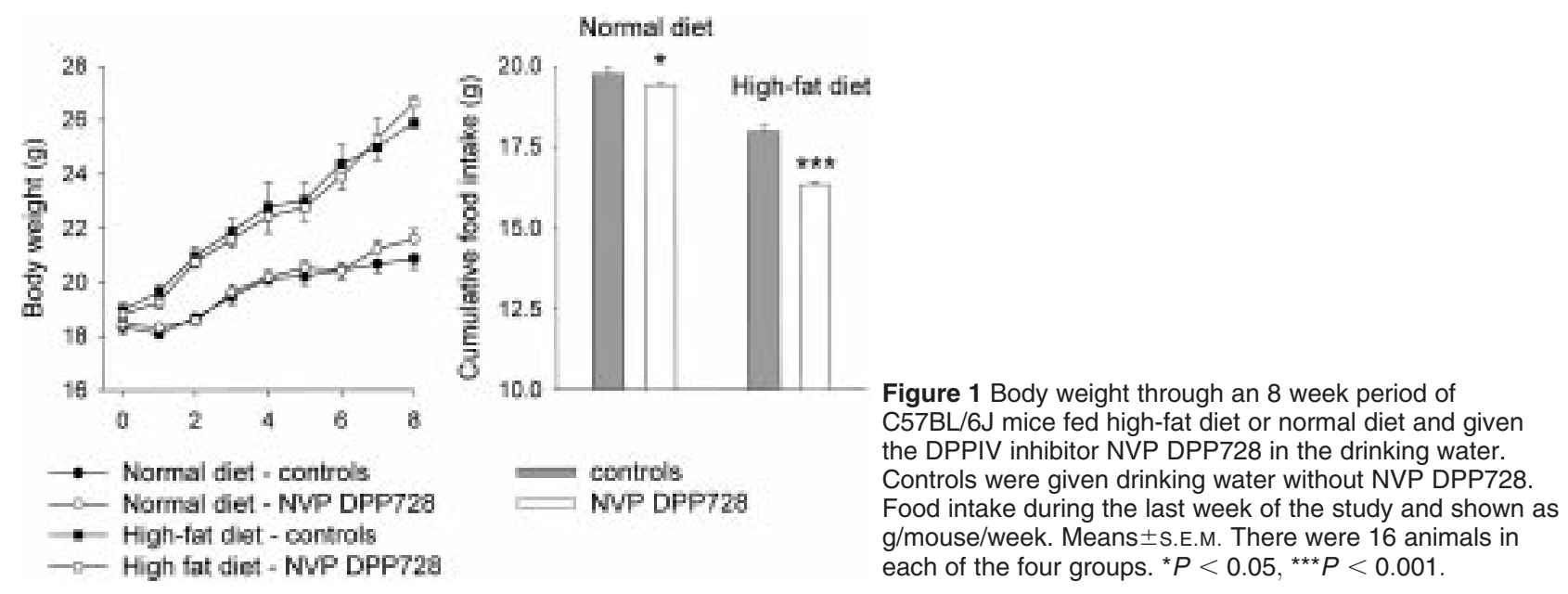

www.eje.org 


\section{Normal diet; week 4}
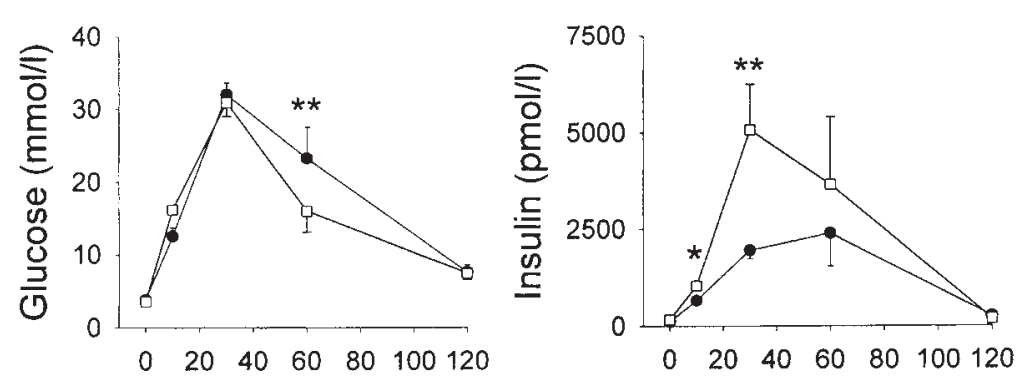

\section{Normal diet; week 8}
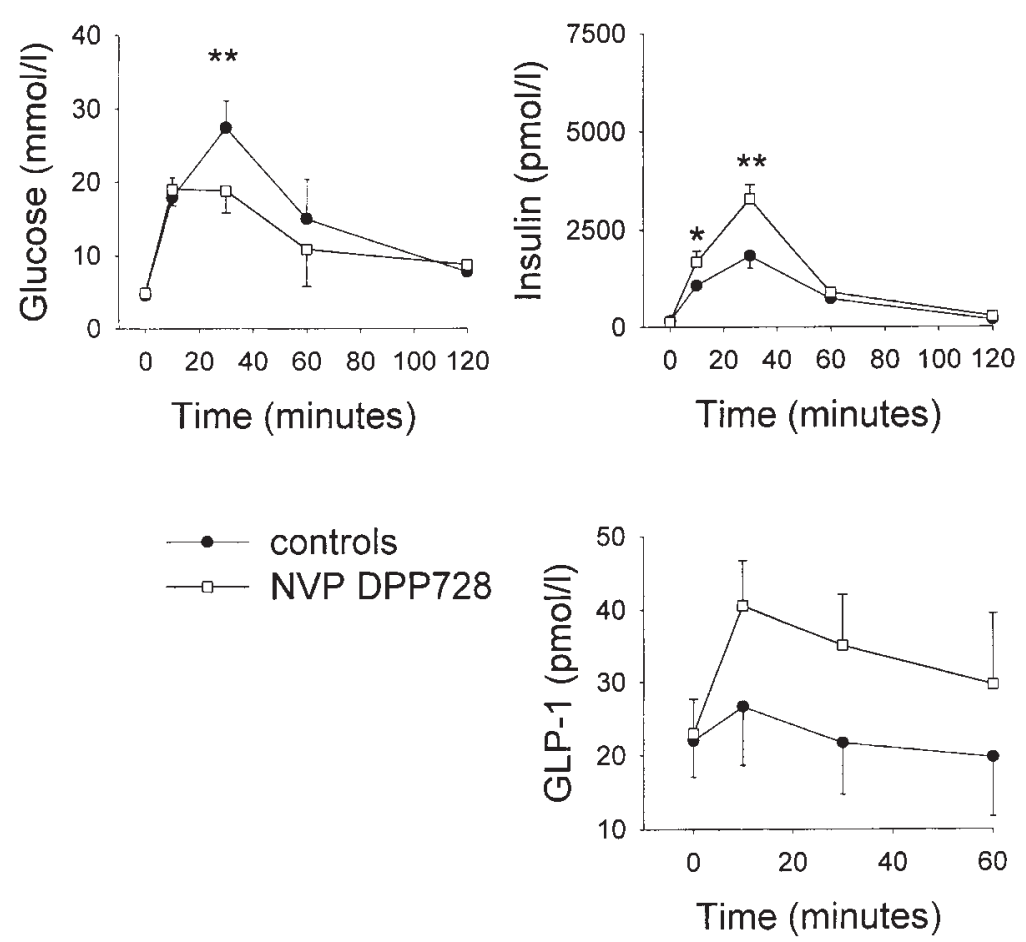

Figure 2 Plasma levels of glucose and insulin after administration of glucose $(150 \mathrm{mg})$ through oral gavage to $\mathrm{C} 57 \mathrm{BL} / 6 \mathrm{~J}$ mice which had been fed normal diet and given 4 or 8 weeks of treatment with the DPPIV inhibitor NVP DPP728 in the drinking water. Controls were given drinking water without NVP DPP728. Means \pm S.E.M. There were 16 animals in each of the four groups. The lower right panel displays plasma levels of intact GLP-1 when the two tests were combined. ${ }^{\star} P<0.05,{ }^{* *} P<0.01$.
60 min incubation. Figure 4 shows that in both mice fed normal diet and mice fed high-fat diet an increased insulin response to glucose was evident in the medium range of glucose concentrations in islets isolated from mice given NVP DPP728, when compared with islets isolated from control mice.

\section{Islet morphology and size}

Double immunofluorescence showed that the relative distribution of insulin- and glucagon-containing cells was not changed in animals given NVP DPP728, after feeding either normal diet or high-fat diet
(Fig. 5). Hence, the islet cytoarchitecutre did not differ between the groups; in all groups of mice, the central core of the islet consisted of insulin cells whereas glucagon cells occurred in the peripheral mantle zone. However, the intensity of GLUT-2 immunoreactivity differed between the groups. Thus, although GLUT-2 immunoreactivity was seen in the plasma membrane of the cells in all examined islets its intensity was increased in mice given NVP DPP728 (Fig. 6). By interactively defining the outline of individual islets, islet size was determined. It was found that islet size in mice fed normal diet and given NVP DPP728 was $5.9 \pm 0.6 \times 10^{3} \mu \mathrm{m}^{2} \quad(n=98$ islets from 


\section{High-fat diet; week 4}
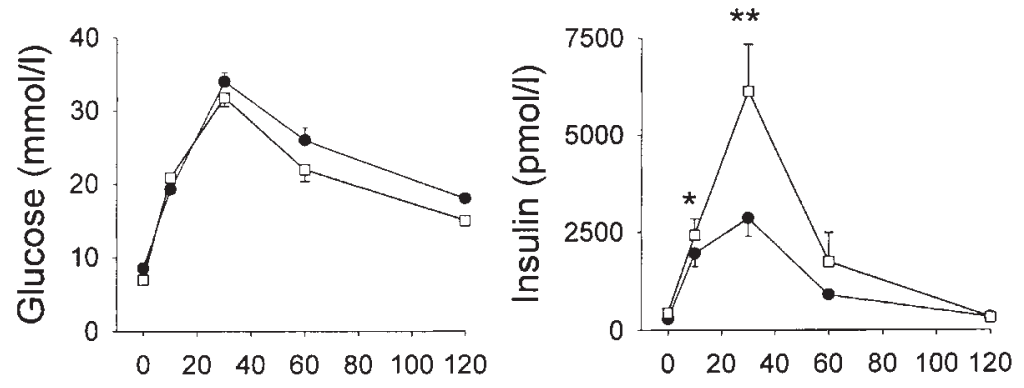

High-fat diet; week 8
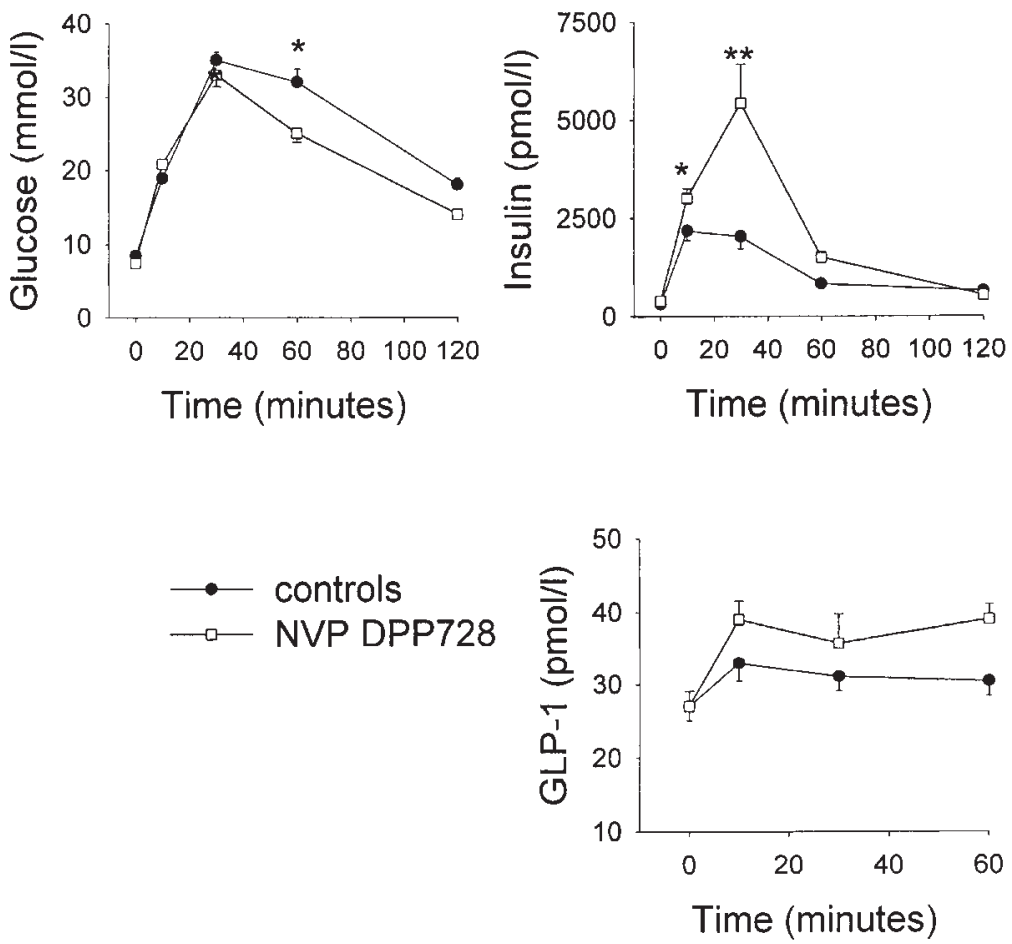

Figure 3 Plasma levels of glucose and insulin after administration of glucose $(150 \mathrm{mg})$ through oral gavage to C57BL/6J mice which had been fed high-fat diet and given 4 or 8 weeks of treatment with the DPPIV inhibitor NVP DPP728 in the drinking water. Controls were given drinking water without NVP DPP728. Means \pm S.E.M. There were 16 animals in each of the four groups. The lower right panel displays plasma levels of intact GLP-1 when the two tests were combined. ${ }^{\star} P<0.05 ;{ }^{\star \star} P<0.01$. five animals) vs $5.6 \pm 0.8 \times 10^{3}(n=59$ islets from five animals) in controls $(P=0.830)$. In mice fed high-fat diet and given NVP DPP728, islet size was significantly lower $\left(7.6 \pm 1.0 \times 10^{3} \mu \mathrm{m}^{2} ; n=75\right.$ islets from five animals) than in controls $\left(16.7 \pm 2.6 \times 10^{3} \mu \mathrm{m}^{2} ; n=74\right.$ islets from five animals, $P=0.0019)$. Hence, NVP DPP728 counteracted the increase in islet size after feeding high-fat diet.

\section{Discussion}

Previous studies on the potential use of DPPIV inhibition in the treatment of diabetes have examined different DPPIV inhibitors in short-term studies only $(16,17,20,21)$. To examine the concept of DPPIV inhibition and improvement of glucose tolerance on a more long-term basis, this study examined the influence of DPPIV inhibition over an 8 week period on glucose tolerance, insulin secretion and islet morphology in normal and glucose-intolerant mice. As long-term inhibition, we used the DPPIV inhibitor NVP DPP728, which has been shown to be orally active, highly potent and highly selective for inhibition of the enzyme (29). We also verified in this study that administration of the substance in the drinking water markedly reduced plasma DPPIV activity. The main finding of the study is that 8 weeks of continuous

www.eje.org 
Table 1 Baseline glucose and insulin levels and the suprabasal AUCs for glucose (120 min) and insulin (60 min) after gastric glucose in C57BL/6J mice fed high-fat diet and mice fed normal diet given the DPPIV inhibitor NVP DPP728 in the drinking water for 8 weeks. Controls were given drinking water without NVP DPP728. The experiments were undertaken after 4 and 8 weeks. Means \pm S.E.M. are shown. There were 16 animals in each of the four groups.

\begin{tabular}{|c|c|c|c|c|c|}
\hline \multirow[b]{2}{*}{ Week } & \multirow[b]{2}{*}{ Variable } & \multicolumn{2}{|c|}{ Normal diet } & \multicolumn{2}{|c|}{ High-fat diet } \\
\hline & & Controls & NVP DPP728 & Controls & NVP DPP728 \\
\hline \multirow[t]{4}{*}{4} & Glucose (mmol/l) & $3.7 \pm 0.3$ & $3.5 \pm 0.2$ & $5.6 \pm 0.3$ & $6.1 \pm 0.3$ \\
\hline & Insulin (pmol/l) & $112 \pm 9$ & $167 \pm 27$ & $213 \pm 28$ & $238 \pm 29$ \\
\hline & AUC $_{\text {glucose }}(\mathrm{mmol} / \mathrm{l} \times 120 \mathrm{~min})$ & $1534 \pm 211$ & $1214 \pm 89^{*}$ & $1815 \pm 109$ & $1679 \pm 100$ \\
\hline & $A U C_{\text {insulin }}(\mathrm{nmol} / \mathrm{I} \times 60 \mathrm{~min})$ & $90 \pm 15$ & $165 \pm 26^{\star \star}$ & $102 \pm 13$ & $175 \pm 26^{*}$ \\
\hline \multirow[t]{4}{*}{8} & Glucose $(\mathrm{mmol} / \mathrm{l})$ & $4.5 \pm 0.2$ & $4.9 \pm 0.2$ & $6.6 \pm 0.2$ & $6.9 \pm 0.4$ \\
\hline & Insulin (pmol) & $152 \pm 25$ & $138 \pm 17$ & $308 \pm 62$ & $397 \pm 29$ \\
\hline & AUC $_{\text {glucose }}(\mathrm{mmol} / / \times 120 \mathrm{~min})$ & $893 \pm 81$ & $605 \pm 60^{*}$ & $1399 \pm 79$ & $1092 \pm 73^{*}$ \\
\hline & $A U C_{\text {insulin }}(\mathrm{nmol} / \mathrm{I} \times 60 \mathrm{~min})$ & $61 \pm 9$ & $91 \pm 9^{*}$ & $80 \pm 9$ & $106 \pm 13^{*}$ \\
\hline
\end{tabular}

${ }^{*} P<0.05,{ }^{* *} P<0.01$ vs without NVP DPP728.
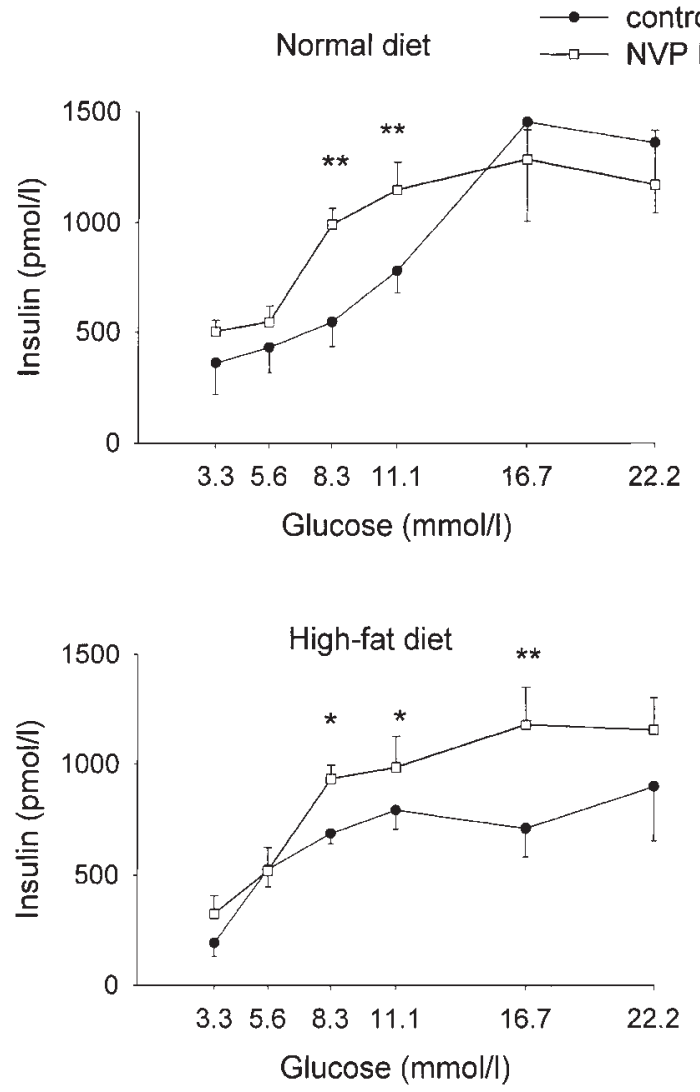

Figure 4 Insulin secretion in response to 60 min incubation of islets in different glucose concentrations. Islets were isolated from C57BL/6J mice which had been fed high-fat diet or control diet and given 8 weeks of treatment with the DPPIV inhibitor NVP DPP728 in the drinking water. Controls were given drinking water without NVP DPP728. Means \pm S.E.M. There were eight animals in each of the four groups. ${ }^{\star} P<0.05,{ }^{*} P<0.01$.

DPPIV inhibition improves glucose tolerance along with increased GLP-1 and insulin levels, augmented insulin secretion and GLUT-2 expression, and reduced (preserved) islet size in glucose-intolerant mice. The study therefore supports the view that DPPIV inhibition improves glucose intolerance also on a long-term basis and that this is due to improved islet function. This extends the previous demonstration that short-term DPPIV inhibition improves glucose tolerance in animal models of diabetes and humans $(16,17,20$, 21) further supporting the potential usefulness of this strategy for the treatment of type 2 diabetes (cf. (8)). Further studies will establish whether also other mechanisms, such as delayed gastric emptying and inhibited glucagon levels or the inactivation of other biologically active peptides of importance for glucose tolerance, such as GIP, might contribute.

After 8 weeks of treatment, islets were isolated and the glucose-stimulated insulin secretion was examined under in vitro conditions in the absence of continued compound exposure. It was found that the insulin response to glucose was augmented at glucose levels in the medium range of the dose-response curve whereas maximal glucose-stimulated insulin secretion was not increased. This is in agreement with previous results of an increased glucose responsiveness in islets incubated with GLP-1 (35). This action is thus preserved also throughout a long-term treatment period, which is of importance when considering the longterm utility of this treatment for diabetes. The increased glucose sensitivity of the islets after NVP DPP728 might be caused by the increased expression of GLUT-2, as evident by the immunostaining, because GLUT-2 is the protein responsible for facilitated transport of glucose into rodent beta-cells $(34,36)$. Hence, although no direct studies were undertaken on glucose uptake or glucose utilization, it may be proposed that long-term treatment with DPPIV inhibition will through increased GLUT-2 expression augment glucose uptake, eliciting a more pronounced insulin response for a given circulating glucose level, in analogy to the reduced glucose-stimulated insulin secretion observed in GLUT-2-null islets (37) and the reduction of islet GLUT-2 expression accompanying development of diabetes in animal models (38). 


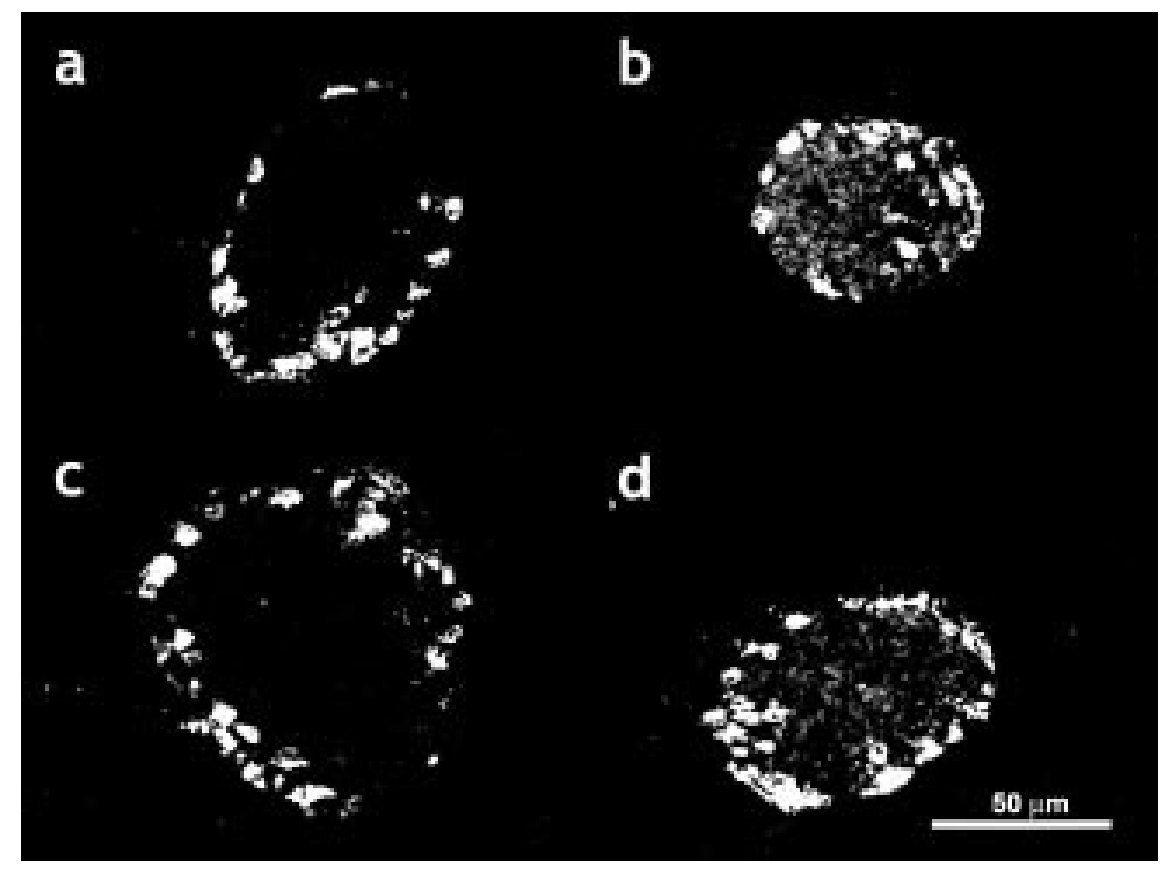

Figure 5 Immunofluorescence staining for insulin and glucagon of pancreatic sections from $\mathrm{C} 57 \mathrm{BL} / 6 \mathrm{~J}$ mice fed a normal diet $(a, b)$ or a high-fat diet (c, d) and given 8 weeks of treatment with the DPPIV inhibitor NVP DPP728 in the drinking water $(b, d)$. Controls were given drinking water without NVP DPP728 (a, c). Insulin (grey staining) is contained in the core zone of the islet, while glucagon (white staining) is found in the mantle zone. The cytoarchitecture of the islet is not disturbed in response to treatment. However, islets from mice given NVP DPP728 were consistently smaller than islets from control mice. As expected, islets from high-fat diet mice were larger than islets from mice fed normal diet.

GLP-1 has been shown to stimulate beta-cell differentiation and growth, mainly through augmentation of the expression of transcription factors such as PDX1 (24). It would therefore potentially be expected that long-term DPPIV inhibition would increase islet size and beta-cell mass. However, we found in control mice that islet size was not affected by the long-term DPPIV inhibition. We also found that in conjunction with the improved glucose tolerance and increased insulin secretion, DPPIV inhibition reduced islet size in mice fed a high-fat diet. This is in analogy to a recent study showing that a 2 week administration of the GLP-1 analogue NN2211 improves glucose tolerance and insulin secretion in Zucker diabetic fatty rats, without any increase in islet mass (39). We interpret these findings as being the consequence of improved islet function, reducing the potent stimuli for increase in islet mass which is exerted by hyperglycemia. Hence, a long-term reduction of the stimuli for islet regeneration in severe insulin resistance in combination with preserved islet function might have developed after DPPIV inhibition. This action is apparently observed without any improvement in insulin resistance per se, as evident by the results that baseline insulin levels were not reduced by NVP DPP728 in mice fed high-fat diet and that there seemed to be a discrepancy between the magnitude of effects on insulin and glucose levels after oral glucose in mice fed normal diet. Thus, insulin levels seemed disproportionally increased in relation to improvement of glucose tolerance. The potential effect of GLP-1 or GLP-1 receptor agonism on insulin sensitivity is controversial, because studies demonstrating both a stimulation of insulin sensitivity $(40,41)$ and no effect $(42,43)$ have been reported, and in a previous study in mice, we reported that after acute challenge with GLP-1, insulin sensitivity was transiently reduced (44). Altogether, this suggests that the preservation of islet size in insulin resistance by NVP DPP728 is not explained by reduced insulin resistance, but rather by the improved islet function per se, which diminishes stimuli for increase in islet size, such as the hyperglycemia. When evaluating the relative changes in insulin vs glucose after a glucose challenge in mice, it should also be kept in mind that, in this species, insulin is of lesser relative importance for glucose disappearance rate than is usually observed in humans, because insulin-independent effects, so-called glucose effectiveness, contribute to a larger degree (45). Therefore, the potential influence of NVP DPP728 on insulin sensitivity is difficult to assess from the results in the present study.

It is known that GLP-1 is expressed not only in the intestinal L-cells, but also in brain neurons localized mainly in the solitary tract. These neurons receive afferent information from the gastrointestinal tract and project to the hypothalamus $(46,47)$. Furthermore, GLP-1 receptors are expressed in hypothalamic nuclei of relevance for the regulation of appetite control (48) and when administered in the third cerebral ventricle in rats, GLP-1 induces satiety by an effect inhibited by GLP-1 receptor antagonism (49). GLP-1 may therefore be involved in the regulation of food intake and in light of this it was of interest that mice given NVP DPP728 exhibited a slightly reduced food intake after the 8 week study period. The reduction in food intake was small, however, and not reflected in a 


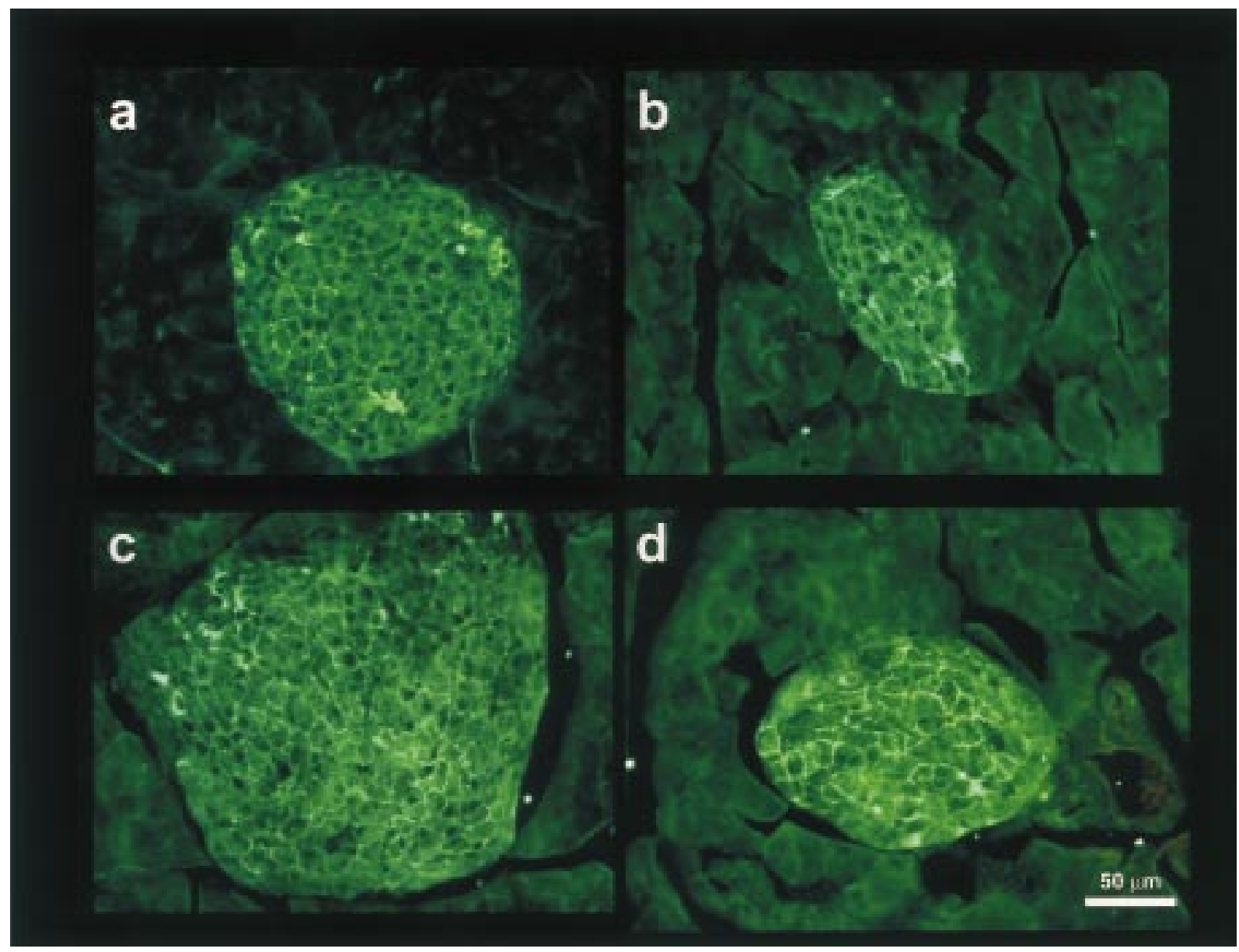

Figure 6 Immunofluorescence staining for GLUT-2 of pancreatic sections from C57BL/6J mice fed a normal diet or a high-fat diet and given 8 weeks of treatment with the DPPIV inhibitor NVP DPP728 in the drinking water. Controls were given drinking water without NVP DPP728. Sections from (a) a control mouse given normal diet, (b) a mouse given normal diet and NVP DPP728, (c) a mouse given high-fat diet, and (d) a mouse given high-fat diet and NVP DPP728. GLUT-2 is localized to the plasma membranes and islets from mice given NVP DPP728 showed consistently more abundant GLUT-2 immunoreactivity. ${ }^{\star} P<0.05,{ }^{\star \star} P<0.01$ vs without NVP DPP728.

reduced body weight. Nevertheless, this adds to the potential usefulness of this approach in the treatment of type 2 diabetes.

Although DPPIV is the enzyme responsible for the degradation of GLP-1 and we found that GLP-1 levels were increased in the mice after long-term DPPIV inhibition, the enzyme is also responsible for the degradation of other biologically active peptides of potential influence on insulin secretion and glucose turnover, as for example the gluco incretin $\operatorname{GIP}(9,10)$. Hence, the beneficial effect of DPPIV inhibition on glucose tolerance might be executed also by these other peptides. To what extent these peptides contribute is, however, not established by the present study. Further studies, for example in GLP-1 receptor-deficient mice (6), are required for establishing the mechanisms involved.

In conclusion, this long-term study in mice rendered glucose-intolerant by feeding a high-fat diet, DPPIV inhibition improves glucose intolerance along with a potentiated insulin secretion, which is due to increased glucose responsiveness of the islets possibly by increased GLUT-2 expression. Furthermore, the improved metabolism by DPPIV inhibition reduces the stimuli for islet hyperplasia/hypertrophy and therefore the increased islet size in insulin-resistant animals, and therefore preserves islet function. The study therefore shows that long-term DPPIV inhibition is feasible for the treatment of glucose intolerance through improvement of islet function and should be further explored as a potential treatment for type 2 diabetes.

\section{Acknowledgements}

The authors thank Dr Thomas E Hughes and Dr Börk Balkan, Novartis, East Hanover, NJ, USA, for valuable comments. The authors are also grateful to Lone Bagger, Lilian Bengtsson, Kerstin Knutsson and Lena 
Kvist for expert technical assistance. The work was supported by grants from the Swedish Research Council (grant no. 6834), Albert Påhlsson, Crafoord, Tage Bluecher, and Novo Nordic Foundations, Swedish Diabetes Association, the Faculty of Medicine, Lund University and the Danish Medical Research Council.

\section{References}

1 Creutzfeldt W. The incretin concept today. Diabetologia 197916 $75-85$.

2 Fehmann HC, Göke R \& Göke B. Cell and molecular biology of the incretin hormones glucagon-like peptide-I and glucose-dependent insulin releasing polypeptide. Endocrine Reviews 199516 390-410.

3 Ahrén B. Glucagon-like peptide 1 (GLP-1) - a gut hormone of potential interest in the treatment of diabetes. BioEssays 1998 20 642-651.

4 Edwards CM, Todd JF, Mahmoudi M, Wang Z, Wang RM, Ghatei MA et al. Glucagon-like peptide 1 has a physiological role in the control of postprandial glucose in humans: studies with the antagonist exendin 9-39. Diabetes 199948 86-93.

5 Tseng CC, Zhang XY \& Wolfe MM. Effect of GIP and GLP-1 antagonists on insulin release in the rat. American Journal of Physiology 1999276 E1049-E1054.

6 Scrocchi LA, Brown TJ, MaClusky N, Brubaker PL, Auerbach AB, Joyner AL et al. Glucose intolerance but normal satiety in mice with a null mutation in the glucagon-like peptide 1 receptor gene. Nature Medicine $199621254-1258$.

7 Miyawaki K, Yamada Y, Yano H, Niwa H, Ban N, Ihara Y et al. Glucose intolerance caused by a defect in the entero-insulinar axis: a study in gastric inhibitory polypeptide receptor knockout mice. PNAS $19999614843-14847$.

8 Holst JJ \& Deacon CF. Inhibition of the activity of dipeptidyl-peptidase IV as a treatment for type II diabetes mellitus. Diabetes 1998 47 1663-1670.

9 Mentlein R. Dipeptidyl-peptidase IV (CD26) - role in the inactivation of regulatory peptides. Regulatory Peptides 199985 9-24.

10 Kieffer TJ, McIntosh CH \& Pederson RA. Degradation of glucosedependent insulinotropic polypeptide and truncated glucagonlike peptide 1 in vitro and in vivo by dipeptidyl peptidase IV. Endocrinology $19951363585-3596$.

11 Deacon CF, Johnsen AH \& Holst JJ. Degradation of glucagon-like peptide-1 by human plasma in vitro yields an N-terminally truncated peptide that is a major endogenous metabolite in vivo. Journal of Clinical Endocrinology and Metabolism $1995 \mathbf{8 0}$ 952-957.

12 Deacon CJ, Danielsen P, Klarskov L, Olesen M \& Holst JJ. Dipeptidy peptidase IV inhibition reduces the degradation and clearance of GIP and potentiates its insulinotropic and antihyperglycemic effects in anesthetized pigs. Diabetes $2001501588-1597$.

13 Hansen L, Deacon CF, Ørskov C \& Holst JJ. Glucagon-like peptide1-(7-36)amide is transformed to glucagon-like peptide-1-(936)amide by dipeptidyl peptidase IV in the capillaries supplying the L cells of the porcine intestine. Endocrinology 1999140 $5356-5363$

14 Deacon CF, Nauck MA, Meier J, Hucking K \& Holst JJ. Degradation of endogenous and exogenous gastric inhibitory polypeptide in healthy and in type 2 diabetic subjects as revealed using a new assay for the intact peptide. Journal of Clinical Endocrinology and Metabolism $2000 \mathbf{8 5} 3575-3581$.

15 Deacon CF, Hughes TE \& Holst JJ. Dipeptidyl peptidase IV inhibition potentiates the insulinotropic effect of glucagon-like peptide 1 in the anesthetized pig. Diabetes 199847 764-769.

16 Balkan B, Kwasnik L, Miserendino R, Holst JJ \& Li X. Inhibition of dipeptidyl peptidase IV with NVP-DPP728 increases plasma GLP-1 (7-36amide) concentrations and improves oral glucose tolerance in obese Zucker rats. Diabetologia 199942 1324-1331.

17 Ahrén B, Holst JJ, Mårtensson H \& Balkan B. Improved glucose tolerance and insulin secretion by inhibition of dipeptidyl peptidase IV in mice. European Journal of Pharmacology $2000 \mathbf{4 0 4}$ $239-245$.

18 Marguet D, Baggio L, Kobayashi T, Bernard AM, Pierres M, Nielsen PF et al. Enhanced insulin secretion and improved glucose tolerance in mice lacking CD26. PNAS 200097 6874-6879.

19 Nagakura T, Yasua N, Yamazaki K, Ikuta H, Yoshikawa S, Asano $\mathrm{O}$ et al. Improved glucose tolerance via enhanced glucose-dependent insulin secretion in dipeptidyl peptidase IV-deficient Fischer rats. Biochemical and Biophysical Research Communications 2001 $284501-506$.

20 Pederson RA, White HA, Schlenzig D, Pauly RP, McIntosh CHS \& Demuth HU. Improved glucose tolerance in Zucker fatty rats by oral administration of the dipeptidylpeptidase IV inhibitor isoleucine thiazolidide. Diabetes 199847 1253-1258.

21 Ahrén B, Simonsson E, Efendic S, Eriksson J, Båvenholm P, Jansson PA et al. Inhibition of DPPIV by NVP DPP728 improves metabolic control over a 4 week period in type 2 diabetes. Diabetes 200150 (Suppl 2) 104-105.

22 Fehmann HC \& Habener JF. Insulinotropic hormone glucagon-like peptide-1(7-37) stimulation of proinsulin gene expression and proinsulin biosynthesis in insulinoma beta TC-1 cells. Endocrinology $1992130159-166$

23 Drucker DJ, Philippe J, Mojsov S, Chick WL \& Habener JF. Glucagonlike peptide I stimulates insulin gene expression and increases cyclic AMP levels in a rat islet cell line. PNAS 198784 3434-3438.

24 Hui H, Wright C \& Perfetti R. Glucagon-like peptide 1 induces differentiation of islet duodenal homeobox-1-positive pancreatic ductal cells into insulin-secreting cells. Diabetes 200150 $785-796$.

25 Ahrén B, Simonsson E, Scheurink AJW, Mulder H, Myrsén U \& Sundler F. Dissociated insulinotropic sensitivity to glucose and carbachol in high-fat diet-induced insulin resistance in C57BL/6J mice. Metabolism 199746 97-106.

26 Simonsson E \& Ahrén B. Potentiated $\beta$-cell response to non-glucose stimuli in insulin resistant C57BL/6J mice. European Journal of Pharmacology $19983 \mathbf{3 5 0} 243-250$.

27 Fritsche A, Stefan N, Hardt E, Häring H \& Stumvoll M. Characterisation of beta-cell dysfunction of impaired glucose tolerance: evidence for impairment of incretin-induced insulin secretion. Diabetologia $200043852-858$

28 Nauck MA, Heimesaat MM, Ørskov C, Holst JJ, Ebert R \& Creutzfeldt W. Preserved incretin activity of glucagon-like peptide 1 [7-36amide] but not of synthetic human gastric inhibitory polypeptide in patients with type-2 diabetes mellitus. Journal of Clinical Investigation 199391 301-307.

29 Hughes TE, Mone MD, Russell ME, Weldon SC \& Villhauer EB. NVP-DPP728 (1-[[[2-[(5-cyanopyridin-2-yl)amino]ethyl]amino] acetyl]-2-cyano-(S)-pyrrolidine), a slow-binding inhibitor of dipeptidyl peptidase IV. Biochemistry 199938 11597-11603.

30 Kubota T, Flentke GR, Bachovchin WW \& Stollarv BD. Involvement of dipeptidyl peptidase IV in an in vivo immuno response. Clinical and Experimental Immunology 199289 192-197.

31 Gutniak MK, Larsson H, Heiber SJ, Juneskans OT, Holst JJ \& Ahrén B. Potential therapeutic level of glucagon-like peptide-1 achieved in humans by a buccal tablet. Diabetes Care 199619 843-848.

32 Deacon CF, Johnsen AH \& Holst JJ. Human colon produces fully processed glucagon-like peptide-1 (7-36)amide. FEBS Letters $1995372269-272$.

33 Ørskov C, Jeppesen J, Madsbad S \& Holst JJ. Proglucagon products in plasma of noninsulin-dependent diabetics and nondiabetic controls in the fasting state and after oral glucose and intravenous arginine. Journal of Clinical Investigation 199187 415-423.

34 Thorens B, Sarkar HK, Kaback HR \& Lodish HF. Cloning and functional expression in bacteria of a novel glucose transporter present in liver, intestine, kidney, and $\beta$-pancreatic islet cells. Cell $198855281-290$. 
35 Zawalich WS, Zawalich KC \& Rasmussen H. Influence of glucagon-like peptide-1 on beta cell responsiveness. Regulatory Peptides $199344277-283$.

36 Malaisse WJ. On the track to the beta-cell. Diabetologia 200144 393-406.

37 Guillam MT, Dupraz P \& Thorens B. Glucose uptake, utilization, and signaling in GLUT2-null islets. Diabetes $2000 \mathbf{4 9}$ $1485-1491$.

38 Unger RH. Diabetic hyperglycemia: link to impaired glucose transport in pancreatic $\beta$-cells. Science 1991251 1200-1205.

39 Gotfredsen CF, Rolin B, Sturis J, Wilken H, Nygaard H, Carr RD et al. NN2211, a long-acting GLP-1 derivative, ameliorates glycemia and reduces triglyceride levels in pre-diabetic ZDF rats in the absence of increased $\beta$-cell mass. Diabetologia 200144 (Suppl 1) A196.

40 Sandhu H, Wiesenthal S, MacDonald PE, McCall R, Tchipashvilli V, Rashid S et al. Glucagon-like peptide-1 increases insulin sensitivity in depanreatized dogs. Diabetes $1999 \mathbf{4 8} 1045-1053$.

41 Young AA, Gedulin BR, Bhavsar S, Bodkin N, Jodka C, Hansen B et al. Glucose-lowering and insulin sensitizing actions of exendin4: studies in obese diabetic (b/ob, db/db) mice, diabetic fatty Zucker rats, and diabetic rhesus monkeys (Macaca mulatta). Diabetes 199948 1026-1034.

42 Ørskov L, Holst JJ, Möller J, Ørskov C, Möller N, Alberti KG et al. GLP-1 does not acutely affect insulin sensitivity in healthy man. Diabetologia $1996391227-1332$.

43 Ahrén B, Larsson H \& Holst JJ. Effects of glucagon-like peptide-1 on islet function and insulin sensitivity in noninsulin-dependent diabetes mellitus. Journal of Clinical Endocrinology and Metabolism 199782 473-478.

44 Ahrén B \& Pacini G. Dose-related effects of GLP-1 on insulin secretion, insulin sensitivity, and glucose effectiveness in mice. American Journal of Physiology 1999277 E996-E1004.

45 Pacini G, Thomaseth K \& Ahrén B. Contribution to glucose intolerance of insulin-independent vs insulin-dependent mechanisms in mice. American Journal of Physiology 2001281 E693-E703.

46 Jin SL, Han VK, Simmons JG, Towle AG, Lauderm JM \& Lund PK. Distribution of glucagon-like peptide I (GLP I), glucagon and glicentin in the rat brain: an immunocytochemical study. Journal of Comparative Neurology 1988271 519-532.

47 Holst JJ. Enteroglucagon. Annual Review of Physiology 199757 257-271.

48 Alvarez E, Roncero I, Chowen JA, Thorens B \& Blazquez E. Gene expression of the rat glucagon-like peptide-1 (GLP-1) receptor in rat brain. Journal of Neurochemistry $1996 \mathbf{6 6} 920-927$.

49 Tang-Christensen M, Larsen PJ, Göke R, Fink-Jensen A, Jessop DS, Møller $M$ et al. Central administration of GLP-1(7-36) amide inhibits food and water intake in rats. American Journal of Physiology 1996271 R848-R856.

Received 11 December 2001

Accepted 13 February 2002 